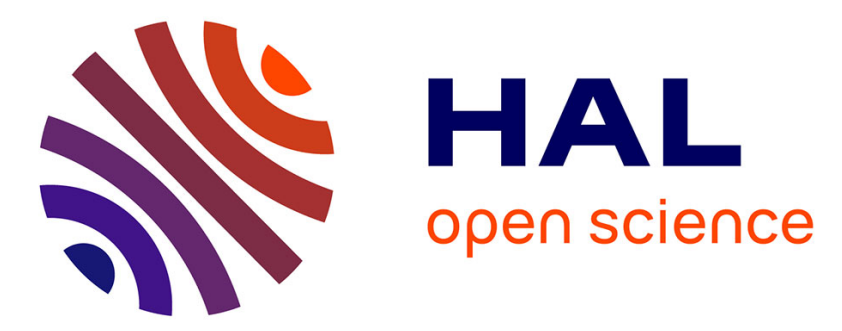

\title{
An electrochemical and SEM study of the mechanism of formation, morphology, and composition of titanium or zirconium fluoride-based coatings
}

Stéphane Verdier, Nicole K. van Der Laak, Francis Dalard, James B. Metson, Stéphane Delalande

\section{To cite this version:}

Stéphane Verdier, Nicole K. van Der Laak, Francis Dalard, James B. Metson, Stéphane Delalande. An electrochemical and SEM study of the mechanism of formation, morphology, and composition of titanium or zirconium fluoride-based coatings. Surface and Coatings Technology, 2006, 200 (9), pp.2955-2964. 10.1016/j.surfcoat.2004.10.139 . hal-02483659

\section{HAL Id: hal-02483659 \\ https://hal.science/hal-02483659}

Submitted on 2 Oct 2020

HAL is a multi-disciplinary open access archive for the deposit and dissemination of scientific research documents, whether they are published or not. The documents may come from teaching and research institutions in France or abroad, or from public or private research centers.
L'archive ouverte pluridisciplinaire HAL, est destinée au dépôt et à la diffusion de documents scientifiques de niveau recherche, publiés ou non, émanant des établissements d'enseignement et de recherche français ou étrangers, des laboratoires publics ou privés. 


\title{
An electrochemical and SEM study of the mechanism of formation, morphology, and composition of titanium or zirconium fluoride-based coatings
}

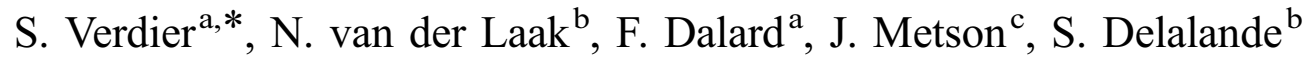 \\ ${ }^{a} I N P$ Grenoble, Laboratoire d'Electrochimie et de Physico-chimie des Matériaux et des Interfaces, CNRS UMR 5631, BP 75, \\ 38402 St-Martin-d'Heres Cedex, France \\ ${ }^{\mathrm{b}}$ PSA Peugeot-Citroën, Centre Technique de Vélizy, 78943 Vélizy-Villacoublay, France \\ ${ }^{\mathrm{c}}$ The University of Auckland, Chemistry Department, 23 Symonds St., Auckland, New Zealand
}

\begin{abstract}
Electrochemical rest potential and cyclic voltametry were used to investigate the behaviour of the 6\% Al magnesium alloy AM60 in various zirconium or titanium fluoride aqueous acid solutions. These solutions have a wide range of aggressiveness with respect to AM60 due largely to fluoride concentration and in some cases to their highly acidic nature. The morphology and composition of the resulting film have been determined by Scanning Electron Microscopy (SEM), and Energy Dispersive X-ray spectroscopy (EDX). The film nucleation is promoted by a $\mathrm{pH}$ increase due to water reduction and is thus more likely to occur on the cathodic parts of the surface. Correlatively, film formation on the anodic primary solid solution occurred in only one solution.
\end{abstract}

Keywords: Zirconium/titanium coatings; Magnesium alloy; SEM; Electrochemistry

\section{Introduction}

The need for car manufacturers to improve the overall energy efficiency of automobiles has led to the use light alloys to minimize the vehicle weight and to reduce exhaust gas emissions. Aluminium and magnesium alloys are the most widely promising materials for car body panels' weight reduction. Despite their good mechanical properties such as a high strength to weight ratio, magnesium alloys have found limited application due largely to poor corrosion resistance. The corrosion resistance of magnesium is significantly improved by alloying, in particular with

\footnotetext{
* Corresponding author. Tel.: +64 93737599 82983; fax: +64 93737925. E-mail addresses:stephaneverdier@hotmail.com, s.verdier@auckland.ac.nz (S. Verdier).
}

aluminium and manganese or zinc [1] and limiting the content of impurities [2]. However, such alloys must undergo surface treatment and organic coating before being incorporated in car body panels. The surface treatment aims to increase corrosion resistance and/or improve organic coating adhesion. Chromate conversion coatings typically meet these two requirements for magnesium alloy substrates. However, treatments based on hexavalent chromium are no longer acceptable due to toxicity problems.

Thus, it is necessary to develop chrome-free surface treatments before using magnesium alloys for structural applications. There are a number of alternatives to hexavalent chromium for protecting magnesium and its alloys [3]. One of these alternatives is surface treatment based on group IV-A fluorides [4]. Hexafluoro-zirconic- or hexafluoro-titanic-based treatments have been developed for aluminium alloys [5-13] and for galvanized or galfan ${ }^{\circledR}$ 
coated steel $[14,15]$. On the former alloys, they lead to the formation of a thin layer that is a mixture of aluminium oxyfluoride, titanium dioxide, and zirconium oxyfluoride. However, little is know about the formation of such coatings on magnesium alloys [16-18]. Moreover, all of these studies have used commercial zirconium or titanium solutions, the exact compositions of which were not given.

In a previous work [19], we have studied the electrochemical behaviour and corresponding surface chemistry of AM60 magnesium alloy in fluoride solutions by XPS. The most aggressive solutions were the most concentrated ones, and the $\mathrm{pH}$ had no visible influence on AM60 electrochemical behaviour. The resulting film was a mixture of magnesium hydroxide and a magnesium hydroxyfluoride, approaching $\mathrm{MgF}_{2}$ with increasing fluoration, i.e., for the most fluoride concentrated and acid solutions. We also analysed the surface chemistry of films formed on AM60 magnesium alloy after zirconium or titanium fluoride treatments by means of XPS [20,21]. The experiments showed that it is possible to form a film containing zirconium or titanium at the surface of this alloy. Zirconium is always present in its dioxide form $\mathrm{ZrO}_{2}$, and some hydroxy-oxide or hydroxyfluoride may also be present depending on solution composition used. Titanium was under only one chemical state, the dioxide $\mathrm{TiO}_{2}$. A mechanism of formation was proposed, suggesting that the zirconium or titanium complexes in solution precipitate due to a local increase of $\mathrm{pH}$ taking place since the reduction of water occurs at the surface of AM60.

To complete these previous works, we present here an in situ study of the electrochemical behaviour of AM60 magnesium alloy in $\mathrm{Zr} / \mathrm{Ti}$ treatment solutions followed by the analysis of the resulting film morphology and composition by Scanning Electron Microscopy (SEM) and Energy Dispersive X-ray spectroscopy (EDX).

\section{Experimental}

\subsection{Samples}

The magnesium alloy AM60 used contains 6\% $\mathrm{Al}$ and $0.27 \% \mathrm{Mn}$ by weight. Prior to the experiments, the samples were polished with $\mathrm{SiC} 1200$ grit paper for electrochemical measurements and up to 4000 grit paper for surface analyses, rinsed with distilled water, cleaned in ethanol in an ultrasonic bath, and dried in a warm-pulsed air stream. When needed, the alloy microstructure was revealed by etching $20 \mathrm{~s}$ in a solution containing $20 \mathrm{~mL}$ acetic acid, 1 $\mathrm{mL}$ concentrated nitric acid, $60 \mathrm{~mL}$ ethylene glycol, and 20 $\mathrm{mL}$ deionised water.

\subsection{Solutions}

The surface treatments were performed in a $100 \mathrm{ml}$ polyethylene vessel at room temperature. Solutions were prepared using hexafluoro-zirconic acid $\mathrm{H}_{2} \mathrm{ZrF}_{6}$ and hexafluoro-titanic acid $\mathrm{H}_{2} \mathrm{TiF}_{6}$ solutions supplied by Aldrich. In some cases, fluoride was added using potassium fluoride, KF (Acros), or hydrofluoric acid, $\mathrm{HF}$ (Aldrich). Potassium hydroxide, $\mathrm{KOH}$ (Acros), was added when an increase in $\mathrm{pH}$ was needed. In each case, the sample was immersed for $1 \mathrm{~min}$ and then rinsed with deionised water and dried in warm-pulsed air. All chemicals are reagent grade.

\subsection{Electrochemical setup}

The specimen was placed in a Teflon ${ }^{\circledR}$ and $\mathrm{KELF}^{\circledR}$ based device, leaving exposed an active surface $8 \mathrm{~mm}$ in diameter. This sample was placed in a Rotating Disk Electrode, with a rate of $1000 \mathrm{rpm}$. The auxiliary electrode was a large surface area platinum disk, and the reference electrode was a Saturated Calomel Electrode (SCE). Electrochemical experiments were carried out at constant temperature, using a 1260 Solartron potentiostat. This instrument was piloted by a computer and Scribner Corware/Corview electrochemistry software.

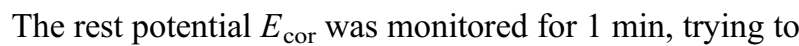
begin the potential acquisition simultaneously with the electrode immersion. After this hold time, three cyclic voltammograms were plotted consecutively from $E_{\text {cor }}$ to $+500 \mathrm{mV} / E_{\text {cor }}$, reverse scan to $-500 \mathrm{mV} / E_{\text {cor }}$ and return to $E_{\text {cor }}$. The scan rate was $10 \mathrm{mV} \mathrm{s}^{-1}$.

\subsection{Surface analyses}

Scanning Electron Microscopy was performed with a LEO Stereoscan 440 microscope equipped with an EDAX analysis apparatus. Unless otherwise specified, the primary electron beam acceleration was $20 \mathrm{kV}$. The electron microprobe analysis was performed on a Cameca Microson SU30 coupled with WDX detectors. The accelerating voltage was set at $8 \mathrm{keV}$, which gives a comparable analysis depth to that of the SEM/EDX analysis.

\section{Results}

\subsection{In situ electrochemical behaviour}

Table 1 shows the composition of the zirconium or titanium fluoride solutions used. The $\mathrm{pH}$ value was

Table 1

Composition of $\mathrm{Zr} / \mathrm{Ti}$ fluoride solutions

\begin{tabular}{llll}
\hline$\left[\mathrm{H}_{2} \mathrm{ZrF}_{6}\right](\mathrm{M})$ & $\mathrm{pH}$ & {$\left[\mathrm{H}_{2} \mathrm{TiF}_{6}\right](\mathrm{M})$} & $\mathrm{pH}$ \\
\hline $10^{-3}$ & 2.9 & $10^{-4}$ & 3.5 \\
$5.10^{-3}$ & 2.2 & $10^{-3}$ & 2.2 \\
$10^{-2}$ & 1.9 & $10^{-2}$ & 1.8 \\
$10^{-1}$ & 1.1 & $10^{-1}$ & 0.8 \\
\hline
\end{tabular}




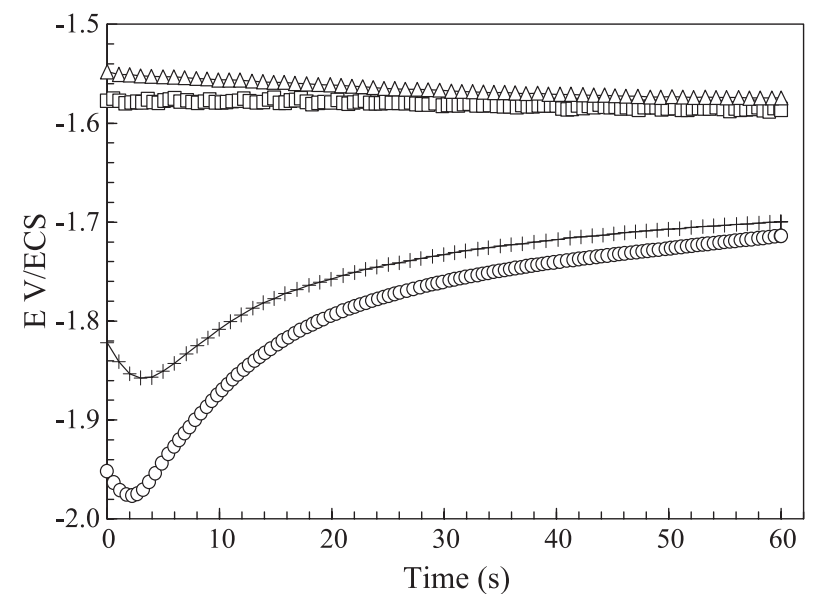

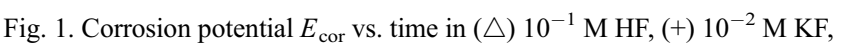
(口) $10^{-1} \mathrm{M}$, and (O) $10^{-3} \mathrm{M} \mathrm{H}_{2} \mathrm{ZrF}_{6}$.

determined using $\mathrm{pH}$ paper because a conventional glass electrode dissolves in the acidic fluoride solutions. The $\mathrm{pH}$ values given below have thus to be considered with a \pm 0.2 confidence interval.

\subsubsection{Zirconium treatments}

The rest potential showed two possible evolutions (Fig. 1). In the first, i.e., in the $10^{-1} \mathrm{M} \mathrm{H}_{2} \mathrm{ZrF}_{6}$ solution, the potential slightly decreased during $1 \mathrm{~min}$, near $-1600 \mathrm{mV} /$ SCE. In all the others solutions, the potential decreased about $50 \mathrm{mV}$ during the first $2-5 \mathrm{~s}$ following immersion and then increased slightly from 10 to $150 \mathrm{mV}$ to reach -1710 to $-2000 \mathrm{mV} / \mathrm{SCE}$ after $1 \mathrm{~min}$.

The comparison with the corrosion potential vs. time curves for AM60 immersed in various fluoride-based solutions [19] showed some similarities. For fluoride solutions, only the $10^{-1} \mathrm{M}$ HF solution $(\mathrm{pH} 1.9)$ gave a potential evolution comparable to the $10^{-1} \mathrm{M} \mathrm{H}_{2} \mathrm{ZrF}_{6}$. This particular evolution is only obtained for the most acid- and fluoride-concentrated solutions and is probably related to an especially high dissolution rate of the magnesium alloy under these conditions. The two step corrosion potential

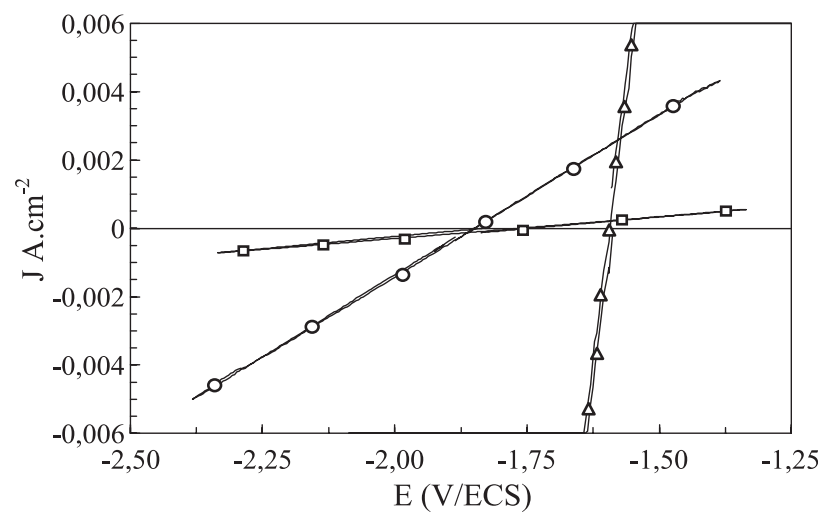

Fig. 2. Current-voltage curves plotted after a preliminary hold time of 1 min at $E_{\text {cor }} \mathrm{H}_{2} \mathrm{ZrF}_{6}(\triangle) 10^{-1} \mathrm{M}$, (O) $10^{-2} \mathrm{M}$, and (口) $10^{-3} \mathrm{M}$ solution.

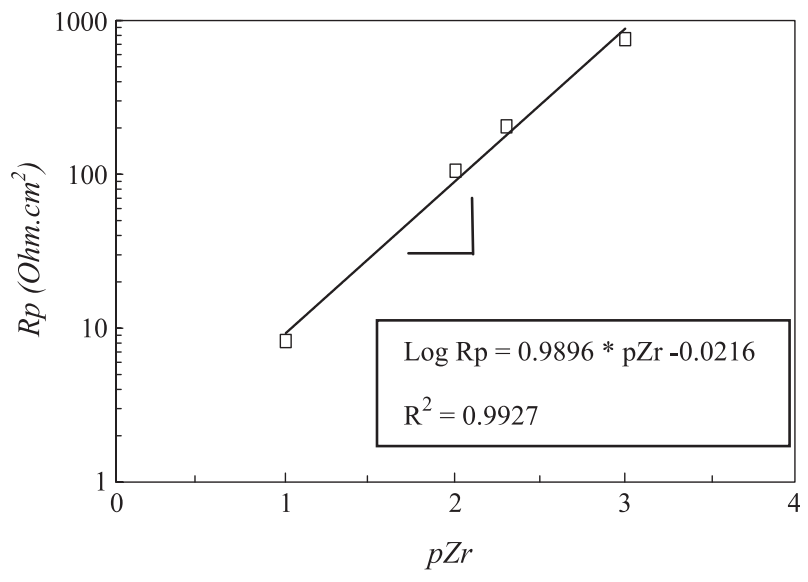

Fig. 3. Polarization resistance for various $\mathrm{pZr}$ solutions, first scan, after a preliminary hold time of $1 \mathrm{~min}$ at $E_{\text {cor }}$.

evolution in most of the solutions can be related to the occurrence of a dissolution step (potential decrease during the first $2-5 \mathrm{~s}$ ) followed by the formation of a more protective film.

The voltammograms (Fig. 2) remained the same from one scan to the next, even in the few five scan experiments performed. This indicates that there is no major evolution of the electrochemical behaviour after the 1-min hold time. Moreover, no current plateau could be observed, even for 1 $\mathrm{V}$ anodic or cathodic overvoltage vs. corrosion potential. The current densities increased with increasing $\mathrm{H}_{2} \mathrm{ZrF}_{6}$ concentrations. This dependence of electrochemical behaviour of AM60 with $\mathrm{H}_{2} \mathrm{ZrF}_{6}$ concentration is pointed out in Fig. 3. The polarization resistance $R_{\mathrm{p}}=(\mathrm{d} E / \mathrm{d} j)_{j=0}$ was determined, and a linear increase in $\log _{10} R_{\mathrm{p}}$ of about 1 per unit $\mathrm{pZr}$, with $\mathrm{pZr}=-\log _{10}\left[\mathrm{H}_{2} \mathrm{ZrF}_{6}\right]$ was observed. The most concentrated solutions are thus the most aggressive with respect to the AM60 alloy.

\subsubsection{Titanium treatments}

Fig. 4 shows the evolution of corrosion potential during $1 \mathrm{~min}$ in $10^{-4}$ to $10^{-1} \mathrm{M} \mathrm{H}_{2} \mathrm{TiF}_{6}$ solutions. For concen-

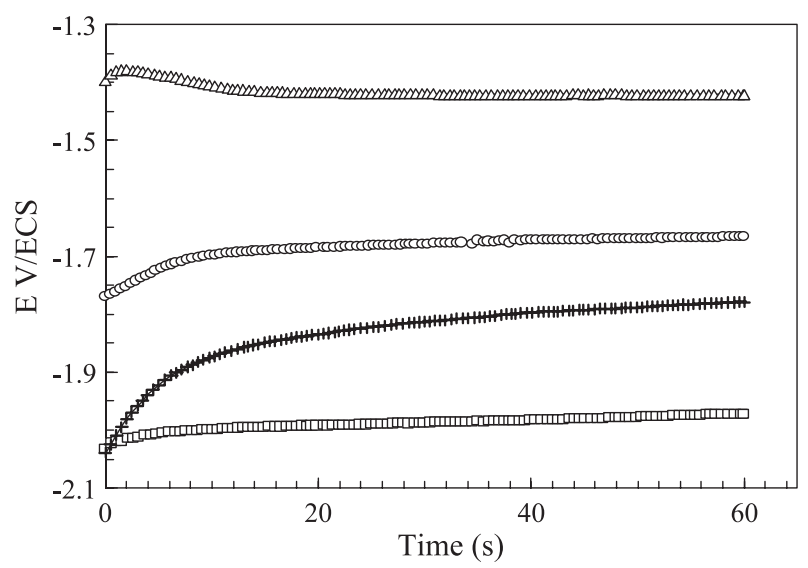

Fig. 4. Corrosion potential $E_{\text {cor }}$ vs. exposure time in $(\triangle) 10^{-1} \mathrm{M}$, (O) $10^{-2}$ $\mathrm{M}$, ( $\square$ ) $10^{-3} \mathrm{M}$, and (+) $10^{-4} \mathrm{M} \mathrm{H}_{2} \mathrm{TiF}_{6}$. 


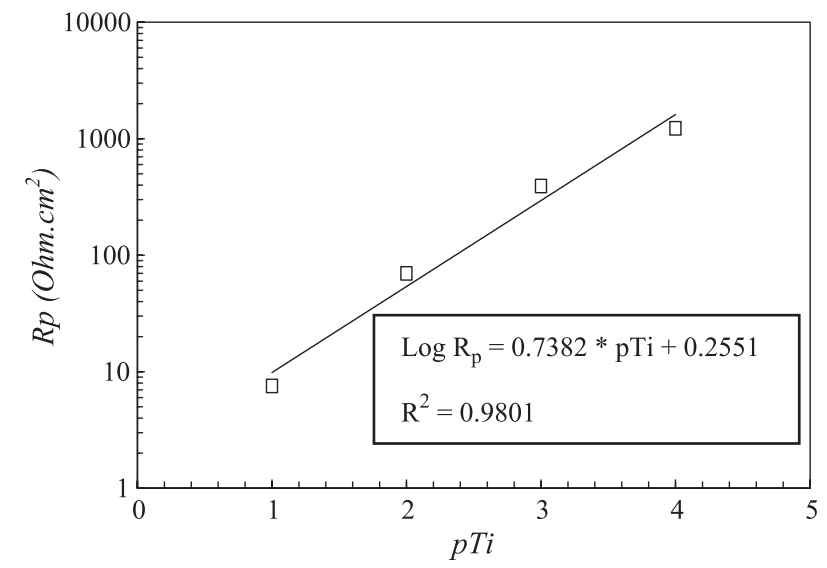

Fig. 5. Polarization resistance for various pTi solutions, first scan, after a preliminary hold time of $1 \mathrm{~min}$ at $E_{\text {cor. }}$.

trations below $10^{-1} \mathrm{M} \mathrm{H}_{2} \mathrm{TiF}_{6}$, the corrosion potential increased quickly during 5 to $10 \mathrm{~s}$ then at a lesser rate to reach a stable value between -1700 and $-1950 \mathrm{mV} / \mathrm{SCE}$. For the most concentrated solution, the potential decreased about $5 \mathrm{mV}$ during the 10 first seconds and reached a stable value near $-1420 \mathrm{mV} / \mathrm{SCE}$. The potential drop observed in the 2-5 first seconds for zirconium-based solution was not observed in the titanium solutions. As for the zirconiumbased solutions, no time dependence of the voltammograms was observed. The current densities were found to be dependent on the fluorotitanic acid concentration, as shown in the plot of polarization resistance vs. pTi (Fig. 5). A linear increase in $\log _{10} R_{\mathrm{p}}$ vs. pTi is observed, as for zirconiumbased solutions, but with a lower slope $(0.74)$. The polarization resistance of concentrated $\left(10^{-1} \mathrm{M}\right)$ solutions of either titanic or zirconic acid are near, but for more dilute solutions, titanic ones gave smaller $R_{\mathrm{p}}$ values. The most concentrated solutions are the most aggressive with respect to the substrate.

\subsection{Film morphology and composition}

\subsubsection{Zirconium treatments}

3.2.1.1. Surface morphology and composition. A film containing zirconium has been formed in each solution except $10^{-3} \mathrm{M} \mathrm{H}_{2} \mathrm{ZrF}_{6}$ (Fig. 6). The film consists of a thin layer (less than $1 \mu \mathrm{m}$ thick) with spheres of 5-7 $\mu \mathrm{m}$ diameter upon it. The films did not cover the entire surface. As seen in the highest magnifications (Fig. 7), the $10^{-1} \mathrm{M} \mathrm{H}_{2} \mathrm{ZrF}_{6}$ treated surface was very rough, as expected in light of the high aggressiveness displayed in the electrochemical analysis. The underlayer became smoother, more compact, and contained more white particles of size around $1 \mu \mathrm{m}$ when decreasing the $\mathrm{H}_{2} \mathrm{ZrF}_{6}$ concentration from $10^{-1}$ to $5.10^{-3}$ M. Only a few particles of size less than $1 \mu \mathrm{m}$ could be seen at these magnifications for the $10^{-3} \mathrm{M} \mathrm{H}_{2} \mathrm{ZrF}_{6}$ treatment (Fig. 7d).

The EDX analyses integrated over large areas for each $\mathrm{H}_{2} \mathrm{ZrF}_{6}$ treatment investigated are reported in Table 2. The EDX $\mathrm{Zr} \mathrm{L}$ peaks for $10^{-1} \mathrm{M} \mathrm{H}_{2} \mathrm{ZrF}_{6}$-treated samples were weak for high-concentration solutions and became more intense as the solution concentration decreased to $5.10^{-3} \mathrm{M}$, as seen by the $\mathrm{Zr}$ atomic concentrations which increased from $0.4 \%$ to $1.5 \%$. At this point, we have to be careful with
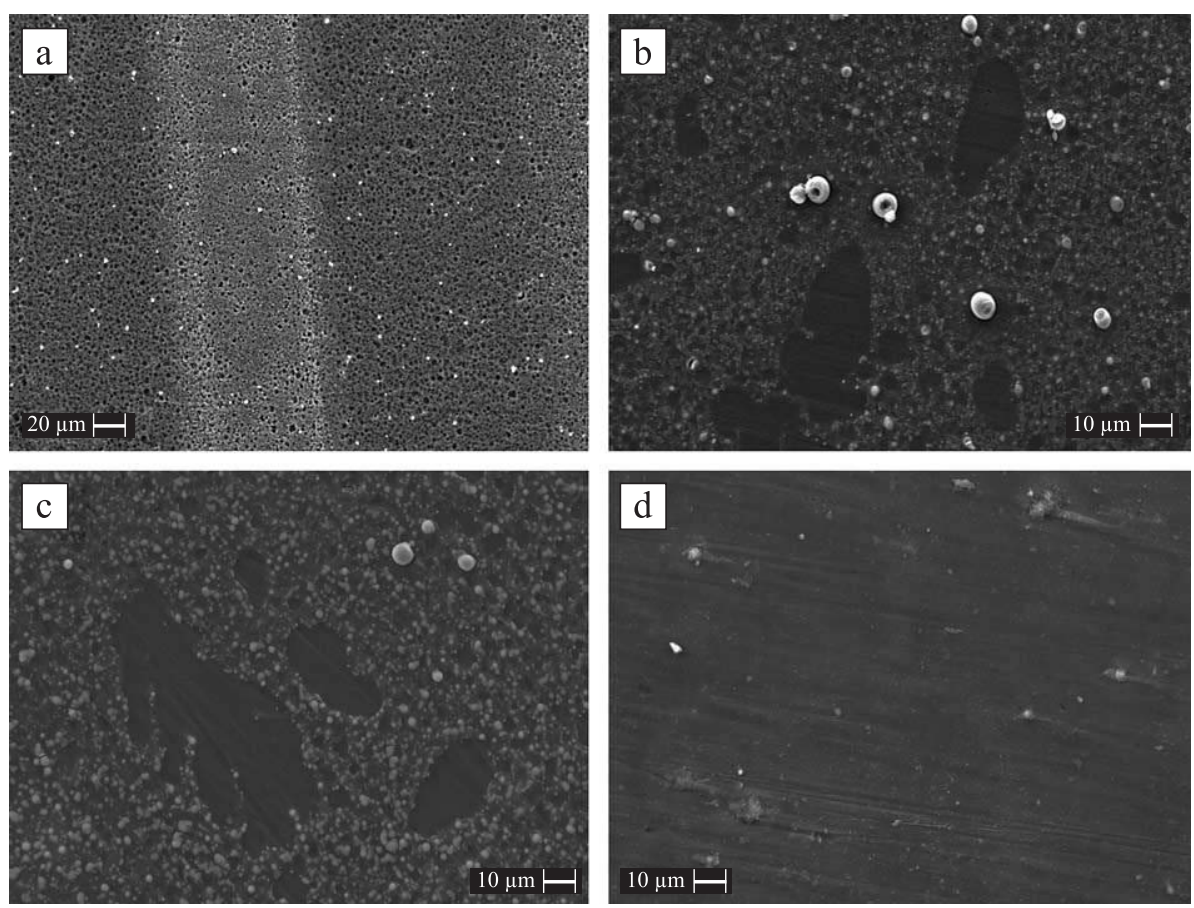

Fig. 6. AM60 surface after (a) $10^{-3} \mathrm{M}$, (b) $10^{-2} \mathrm{M}$, (c) $5.10^{-3} \mathrm{M}$, and (d) $10^{-3} \mathrm{M} \mathrm{H}_{2} \mathrm{ZrF}_{6}$. 

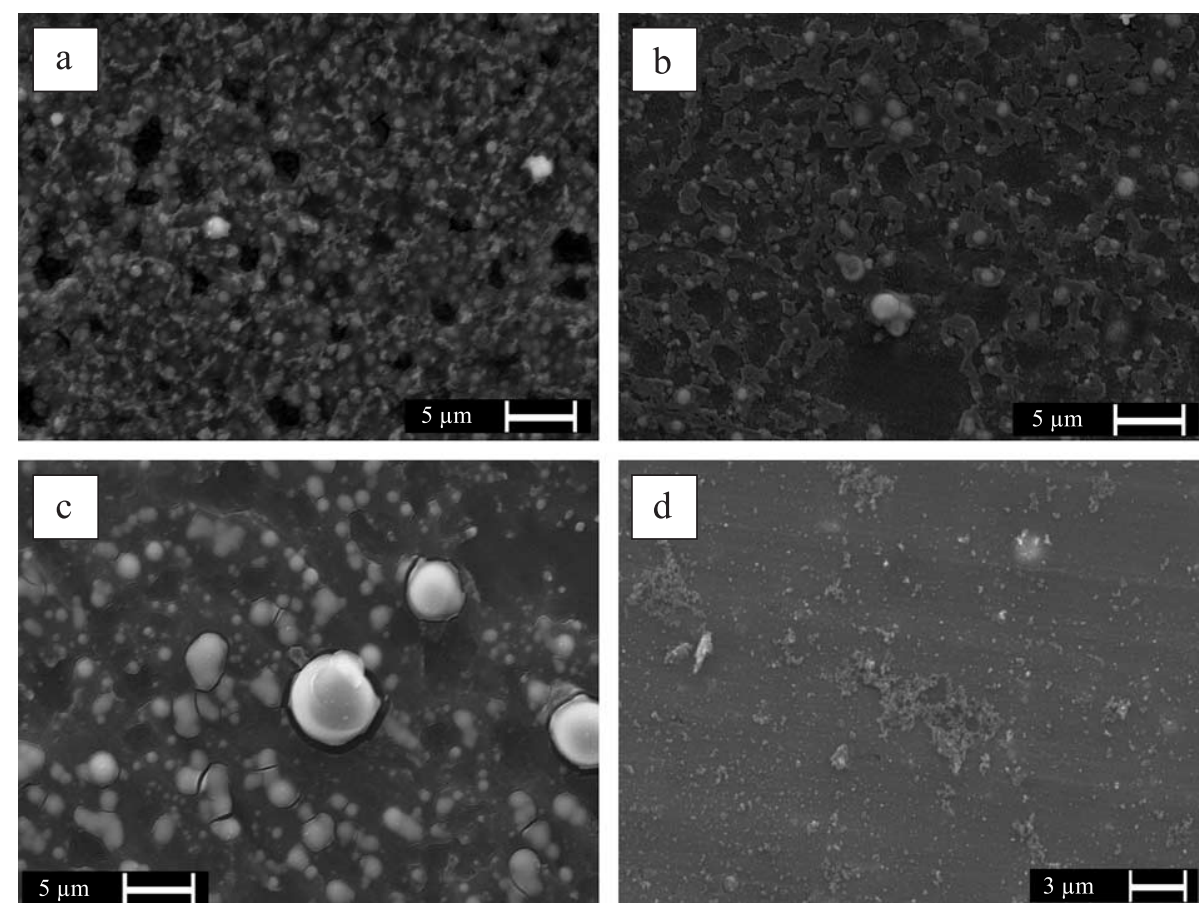

Fig. 7. Film underlayer aspect after (a) $10^{-1} \mathrm{M}$, (b) $10^{-2} \mathrm{M}$, (c) $5.10^{-3} \mathrm{M}$, and (d) $10^{-3} \mathrm{M} \mathrm{H}_{2} \mathrm{ZrF}_{6}$ treatments.

respect to the EDX results since the depth resolution of this technique is in a first approximation a few microns using a $20 \mathrm{kV}$ incident electron beam voltage. The concentrations should thus not be considered as reflecting the exact composition of the film, but one can assume that if the morphology and thickness of the various films are similar from one sample to another, then one can compare the respective EDX analyses. The results presented in Table 2 suggest that an optimum $\mathrm{H}_{2} \mathrm{ZrF}_{6}$ concentration exists that lead to the formation of a zirconium film. The fluoride concentration in the film remained low even for the films of highest zirconium content, which suggests that zirconium is mostly in an oxide or oxyhydroxide form rather than fluoride.

3.2.1.2. Local composition. To investigate the local composition of the film, some EDX point analyses were carried out. Results from these experiments are given in Table 3. Zirconium is present after $10^{-3} \mathrm{M} \mathrm{H}_{2} \mathrm{ZrF}_{6}$ treatment under the form of dispersed submicron scale particles or over the manganese-rich particles, previously observed [22] at the surface of this alloy. For the other solutions, the EDX results confirm the absence of zirconium

Table 2

EDX analyses after zirconium treatments

\begin{tabular}{lllllll}
\hline $\mathrm{H}_{2} \mathrm{ZrF}_{6}(\mathrm{M})$ & $\mathrm{Mg}$ & $\mathrm{Al}$ & $\mathrm{O}$ & $\mathrm{F}$ & $\mathrm{Zr}$ & $\mathrm{Mn}$ \\
\hline $10^{-1}$ & 85.1 & 6.9 & 5.9 & 1.7 & 0.42 & - \\
$10^{-2}$ & 84.1 & 8.2 & 5.5 & 1.4 & 0.8 & - \\
$5.10^{-3}$ & 80.9 & 6.7 & 9.1 & 1.8 & 1.5 & - \\
$10^{-3}$ & 86.5 & 5.7 & 5.7 & 2.1 & - & - \\
\hline
\end{tabular}

The concentrations are in at. $\%$. on the uncovered surface. Moreover, aluminium depletion is associated with these areas, indicating that they are a primary $\alpha$ solid solution [22]. SEM observations of AM60 after revealing the microstructure by etching (Fig. 8) and the corresponding line analysis show that this segregation effect is due to the eutectic solidification.

Microprobe analysis after treatment in $10^{-3} \mathrm{M} \mathrm{HF}+$ $5 \times 10^{-3} \mathrm{M} \mathrm{H}_{2} \mathrm{ZrF}_{6}$ (which corresponds approximately to the $5 \times 10^{-3} \mathrm{M} \mathrm{H}_{2} \mathrm{ZrF}_{6}$ treatment) was performed. It was observed (Fig. 9) that the conversion species, i.e., fluorine and zirconium, laterally segregated in the film, and that the segregation appeared to be controlled by the underlying microstructure. Fluorine deposited predominantly over the magnesium-rich primary $\alpha$ phase, while the zirconium appears to deposit over the aluminium-rich phases.

Zirconium is also present in the $6-7 \mu \mathrm{m}$ spheres. In all the cases, a gaseous evolution took place at the sample surface during immersion in the solutions. It is interesting to note that a gel was seen at the surface of the sample when immersed in the $10^{-1}, 10^{-2}$, and $5.10^{-3} \mathrm{M} \mathrm{H}_{2} \mathrm{ZrF}_{6}$ solutions, which moves along the sample in the $10^{-1} \mathrm{M}$ solution for which the gaseous evolution is the most vigorous. Moreover, we observed brighter vertical paths (Fig. 6a) slightly enriched in zirconium at the surface of this latter sample by SEM. These observations will be discussed below.

\subsubsection{Titanium treatments}

3.2.2.1. Surface morphology and composition. The surface resulting from the $10^{-1} \mathrm{M} \mathrm{H}_{2} \mathrm{TiF}_{6}$ treatment (Fig. 10) is apparently not covered by a film, contrary to the $10^{-2}$ 
Table 3

EDX local analyses after zirconium treatments

\begin{tabular}{|c|c|c|c|c|c|c|c|}
\hline $\mathrm{H}_{2} \mathrm{ZrF}_{6}(\mathrm{M})$ & Area & $\mathrm{Mg}$ & $\mathrm{Al}$ & $\mathrm{O}$ & $\mathrm{F}$ & $\mathrm{Zr}$ & $\mathrm{Mn}$ \\
\hline \multirow[t]{3}{*}{$10^{-1}$} & US & 92.9 & 2.1 & 3.2 & 1.8 & - & - \\
\hline & UL & 59.7 & 6.5 & 24.1 & 7.8 & 1.9 & - \\
\hline & $\mathrm{Mn}^{(2)}$ & $27.2 \pm 12.5$ & $23.7 \pm 8.2$ & $23.2 \pm 3.7$ & $12.7 \pm 2.7$ & $1.8 \pm 0.2$ & $11.4 \pm 5.5$ \\
\hline $10^{-2}$ & $\mathrm{~S}^{(2)}$ & $21.9 \pm 8.8$ & $3.4 \pm 0.3$ & $61.1 \pm 8.0$ & $4.9 \pm 0.1$ & $8.7 \pm 0.8$ & - \\
\hline \multirow[t]{3}{*}{$5.10^{-3}$} & $\mathrm{US}^{(3)}$ & $94.3 \pm 0.6$ & $2.0 \pm 0.3$ & $2.2 \pm 0.4$ & $1.5 \pm 0.1$ & - & - \\
\hline & $\mathrm{S}^{(2)}$ & $22.8 \pm 8.9$ & $4.1 \pm 0.3$ & $54.5 \pm 5.2$ & $4.0 \pm 0.6$ & $13.7 \pm 2.4$ & $0.9 \pm 0.3$ \\
\hline & $\mathrm{UL}^{(2)}$ & $55.7 \pm 2.5$ & $4.5 \pm 2.5$ & $30.1 \pm 1.9$ & $2.7 \pm 0.8$ & $7.0 \pm 0.6$ & - \\
\hline \multirow[t]{2}{*}{$10^{-3}$} & Particles ${ }^{(2)}$ & $87.4 \pm 1.3$ & $3.7 \pm 2.3$ & $5.3 \pm 1.8$ & $3.0 \pm 1.7$ & $0.6 \pm 0.1$ & - \\
\hline & $\mathrm{Mn}^{(2)}$ & $41.0 \pm 0.4$ & $12.1 \pm 6.8$ & $29.9 \pm 8.7$ & $10.8 \pm 1.4$ & $0.7 \pm 0.4$ & $5.5 \pm 4.1$ \\
\hline
\end{tabular}

The concentrations are in at.\%. The various investigated areas correspond to US — uncovered surface, UL — under-layer particles, S-white spheres, and Mnmanganese-rich particles. The numbers between brackets give the number of points to obtain the mean value and standard deviation.

and $10^{-3} \mathrm{M}$ solutions. Numerous white spots cover the entire surface after these three treatments. As seen in Fig. $10 \mathrm{a}$, some of them are undermining and are thus cathodic with respect to the alloy matrix. Titanium is absent in the global analyses (Table 4) for $10^{-1}$ and $10^{-2} \mathrm{M}$ treatments, although a film is observed for the latter.

For the $10^{-3} \mathrm{M}$ treatment, titanium is present in the global analysis. The fluorine concentration decreased with
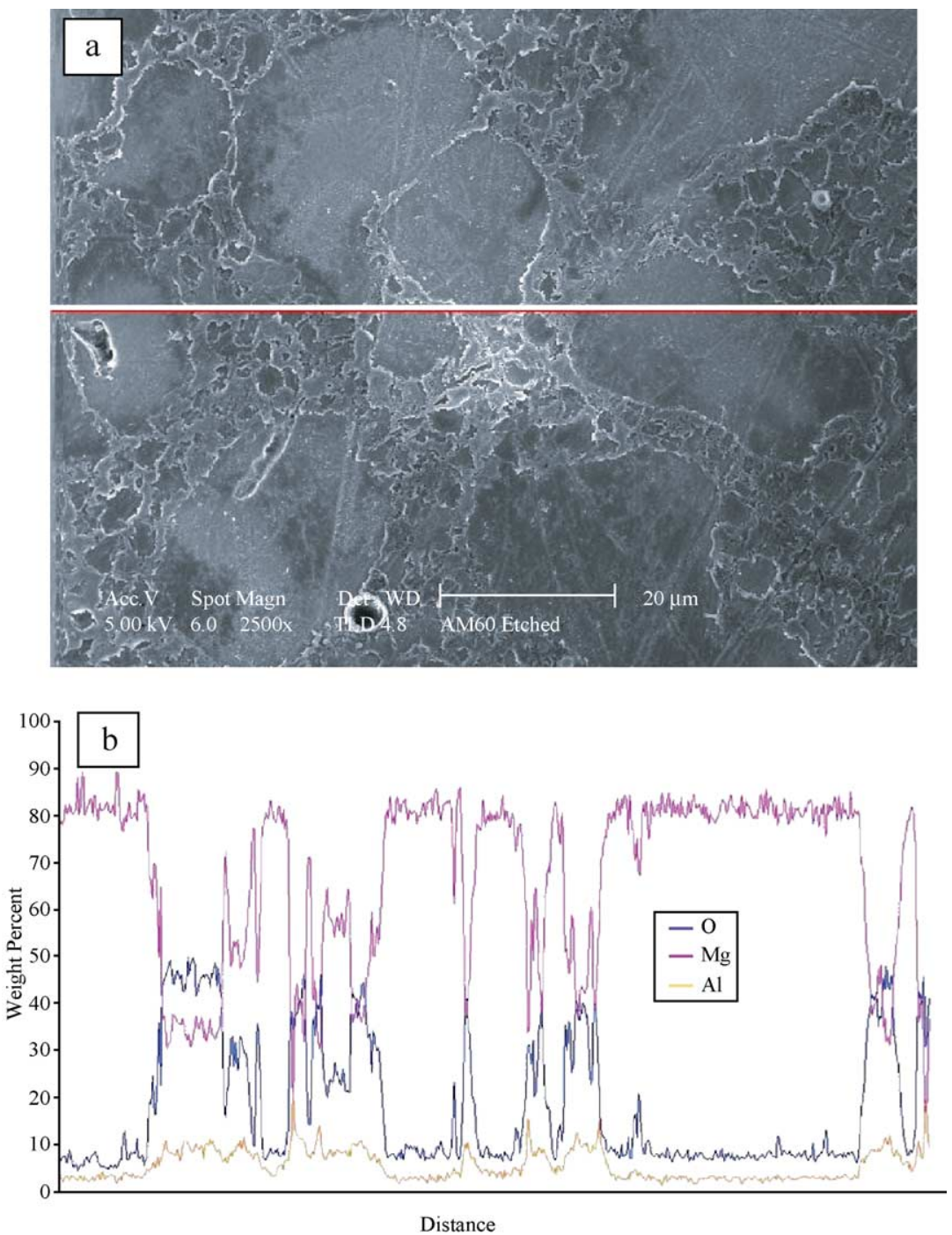

Fig. 8. (a) Microprobe image of AM60 surface after revealing the microstructure by etching and (b) corresponding line analysis of Mg, $\mathrm{Al}$, and $\mathrm{O}$. 

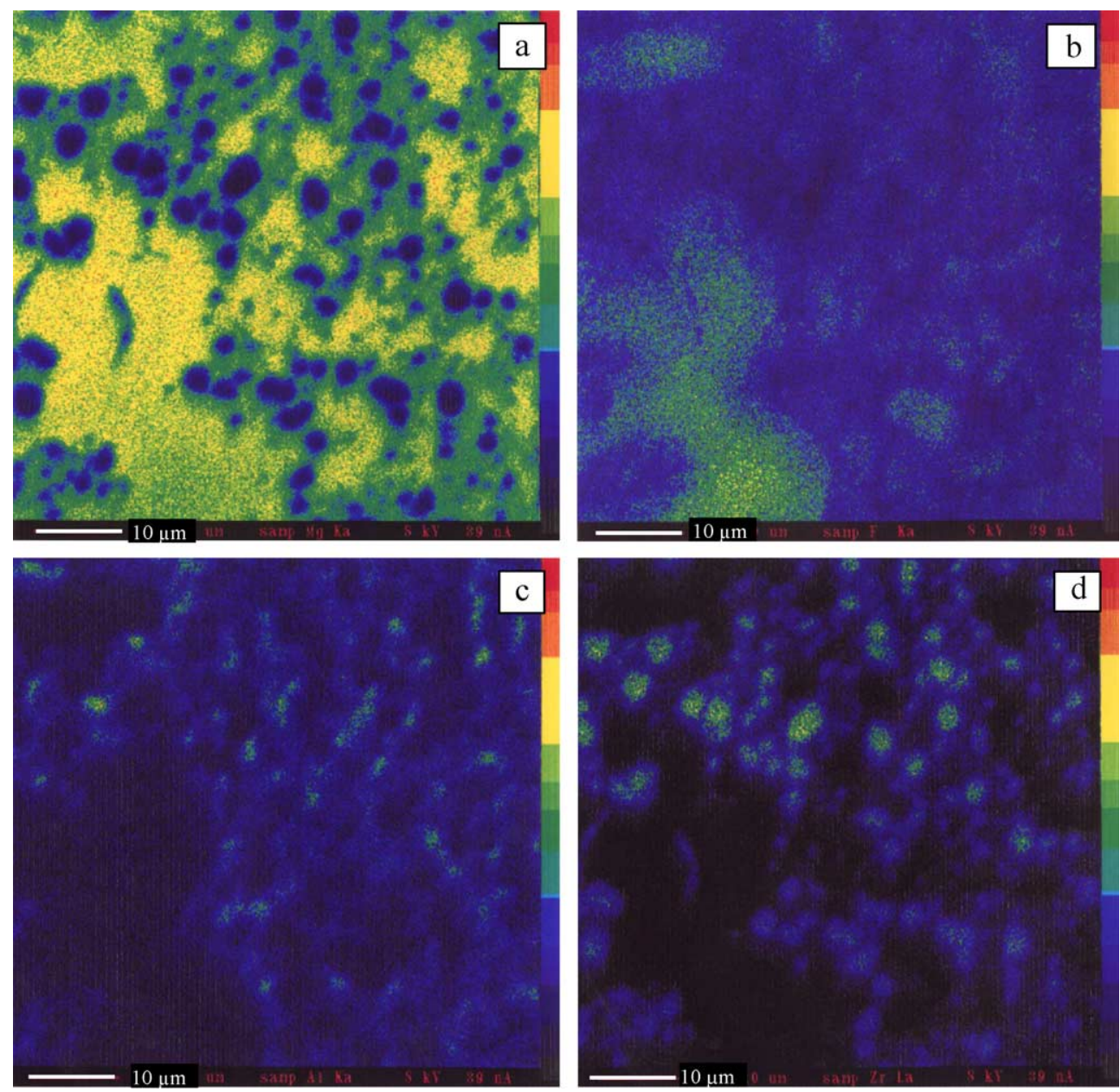

Fig. 9. Microprobe maps of AM60 surface after $10^{-3} \mathrm{M} \mathrm{HF}+5 \cdot 10^{-3} \mathrm{M} \mathrm{H}_{2} \mathrm{ZrF}_{6}$ treatment, (a) $\mathrm{Mg}$, (b) F, (c) Al, and (d) $\mathrm{Zr}$.
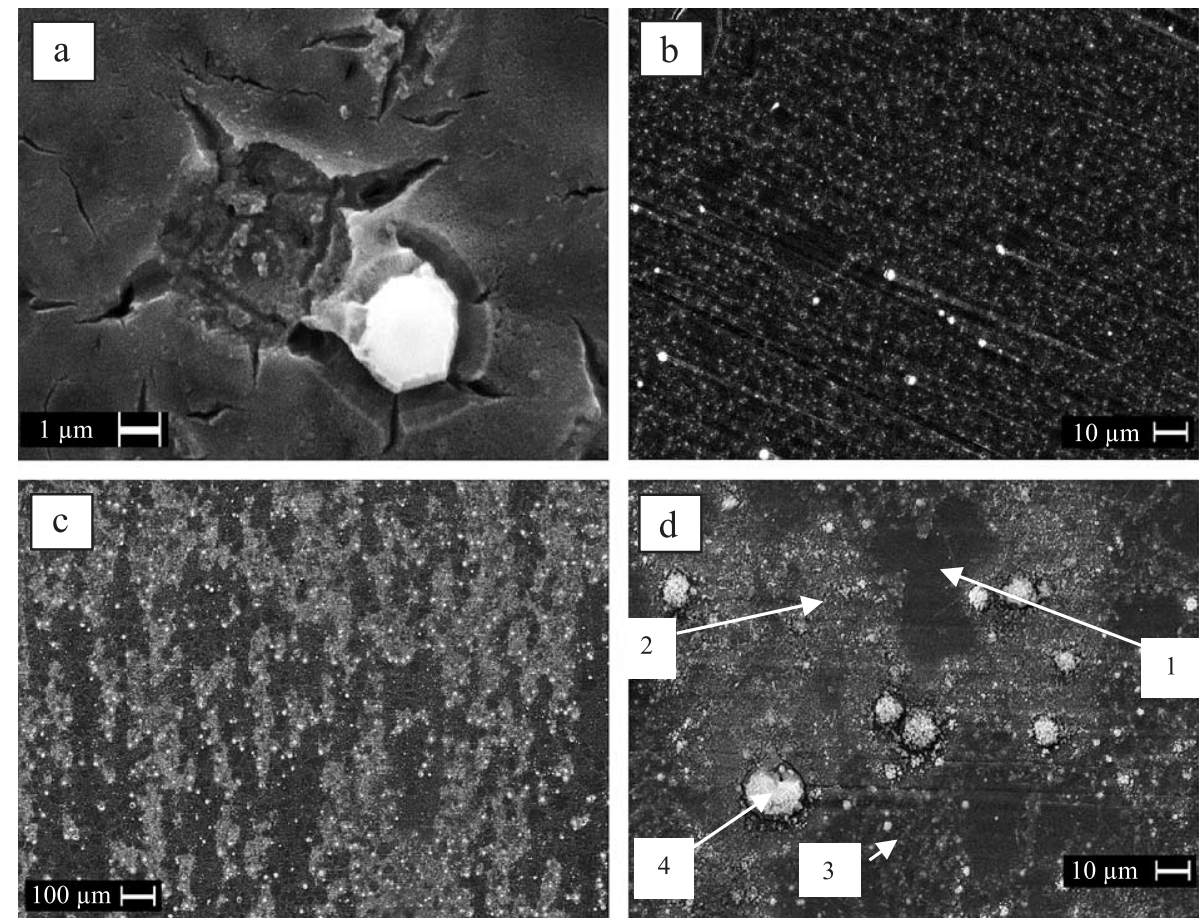

Fig. 10. AM60 surface after (a) $10^{-1} \mathrm{M} \mathrm{H}_{2} \mathrm{TiF}_{6}$, zoom on a Mn undermining particle, (b) $10^{-2} \mathrm{M}$, (c) $10^{-3} \mathrm{M}$, and (d) $10^{-3} \mathrm{M}$, zoom. 
Table 4

EDX analysis after titanium treatments

\begin{tabular}{lllrrrrc}
\hline $\mathrm{H}_{2} \mathrm{TiF}_{6}(\mathrm{M})$ & Area & $\mathrm{Mg}$ & \multicolumn{1}{c}{$\mathrm{Al}$} & \multicolumn{1}{c}{$\mathrm{O}$} & \multicolumn{1}{c}{$\mathrm{F}$} & $\mathrm{Ti}$ & $\mathrm{Mn}$ \\
\hline $10^{-1}$ & Large & 77.7 & 5.1 & 9.8 & 7.4 & - & - \\
& Mn & 38.8 & 12.0 & 29.0 & 14.9 & 0.3 & 5.0 \\
$10^{-2}$ & Large & 81.9 & 6.8 & 7.2 & 4.1 & - & - \\
& Mn & 45.4 & 22.1 & 13.3 & 8.4 & 0.6 & 10.2 \\
$5.10^{-3}$ & Large & 83.9 & 7.2 & 6.8 & 1.6 & 0.5 & - \\
& Sphere & 36.2 & 0.9 & 48.5 & 10.7 & 3.7 & - \\
\hline
\end{tabular}

The concentrations are in at. $\%$.

decreasing $\mathrm{H}_{2} \mathrm{TiF}_{6}$ concentration, in agreement with our previous XPS results [20,21].

3.2.2.2. Local composition. The white cathodic particles contain manganese (Table 3). These particles are also titanium- and fluorine-enriched. As pointed out in Fig. $10 \mathrm{~d}$, the film observed after $10^{-3} \mathrm{M} \mathrm{H}_{2} \mathrm{TiF}_{6}$ treatment is heterogeneous both in a lateral and vertical direction. EDX maps not presented here [22] and local analyses showed that titanium is absent in the dendrites of the primary $\alpha$ solid solution (Fig. 10d-arrow 1), and the film is thicker in some areas (Fig. 10d-arrow 2) than in others (Fig. 10d-arrow 3 ). Some spherical particles of size of a few microns are also observed (Fig. 10d-arrow 4) and were found to contain titanium, oxygen, and fluorine.

\subsubsection{Influence of $p H$}

An increase in zirconium or titanium concentration in the film has previously been observed by XPS [20,21] when increasing the $\mathrm{pH}$ of $5.10^{-3} \mathrm{M} \mathrm{H}_{2} \mathrm{ZrF}_{6}$ and $10^{-3} \mathrm{M} \mathrm{H}_{2} \mathrm{TiF}_{6}$ solutions. The corrosion potential increase observed in this case is heightened (Fig. 11) by increasing the $\mathrm{pH}$ (addition of $\mathrm{KOH}$ ). This evolution could be related to the formation of a more passive or thicker film at the surface of AM60. We simultaneously observed smaller current densities on the voltammograms (Fig. 12). Contrary to the general trend observed in the other solutions, the successive voltammograms (from first to third scan) showed a decrease in anodic

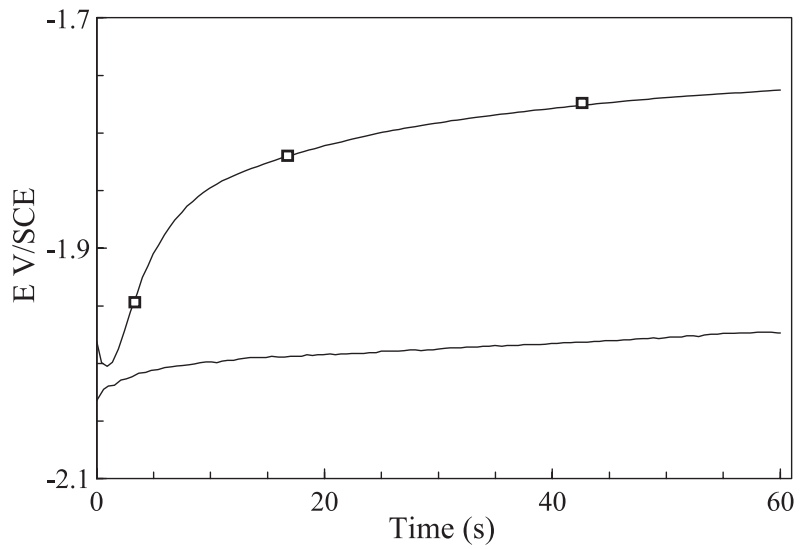

Fig. 11. Corrosion potential of AM60 in $(-) 5 \cdot 10^{-3} \mathrm{M} \mathrm{H}_{2} \mathrm{ZrF}_{6}, \mathrm{pH}=2.2$ ( $\square$ ) $5.10^{-3} \mathrm{M} \mathrm{H}_{2} \mathrm{ZrF}_{6}, \mathrm{pH}=5.3$.
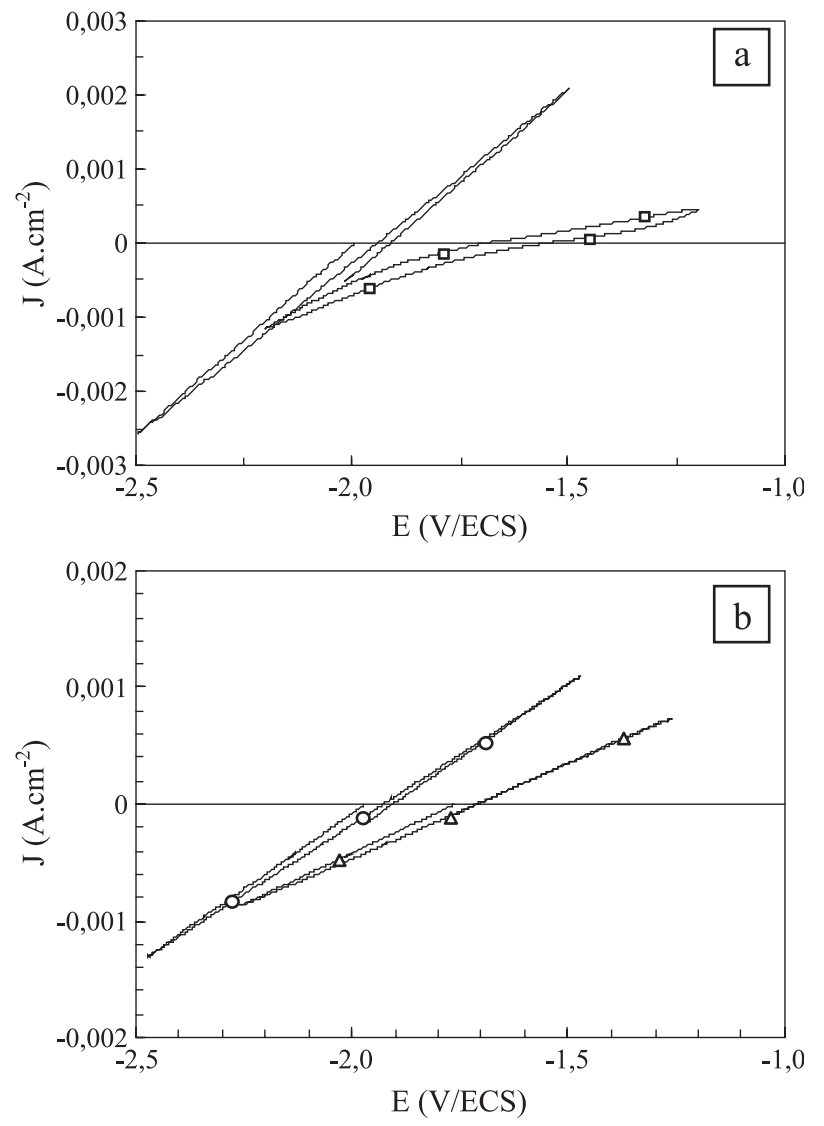

Fig. 12. Current-voltage curves plotted after a preliminary hold time of 1

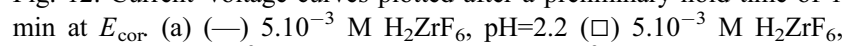

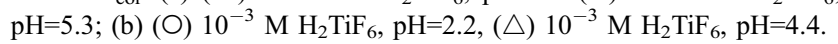

current density. This suggests that, for this solution, a more protective film formed that could provide even better insulating properties for longer immersion time.

\subsubsection{Influence of fluoride ions}

Fig. 13 illustrates the negative effect of fluoride ions' addition on the film formation. For small $\mathrm{KF}$ or $\mathrm{HF}$ additions $\left(10^{-3} \mathrm{M}\right)$, the film has the overall same morphology than without any fluoride addition, but with increasing fluoride concentration, the film progressively disappeared.

These observations are supported by the electrochemical behaviour of AM60. The voltammograms in the $5.10^{-3} \mathrm{M} \mathrm{H}_{2} \mathrm{ZrF}_{6}$ solution with $\mathrm{KF}$ or $\mathrm{HF}$ additions are indeed similar to those obtained without addition of fluoride for low $\left(10^{-3} \mathrm{M}\right) \mathrm{HF}$ or $\mathrm{KF}$ concentrations, and far from the zirconium-free corresponding fluoride solutions, whereas for high $\left(10^{-1} \mathrm{M}\right) \mathrm{HF}$ or $\mathrm{KF}$ concentrations, the voltammograms are similar to those in the zirconium-free HF or KF solutions, and far from the corresponding one without fluoride addition. For medium fluoride additions $\left(10^{-2} \mathrm{M}\right)$, the electrochemical behaviour is intermediate between fluoride-free and zirconiumfree solution. The electrochemical behaviour of AM60 is thus driven by its reactivity with respect to fluoride ions 

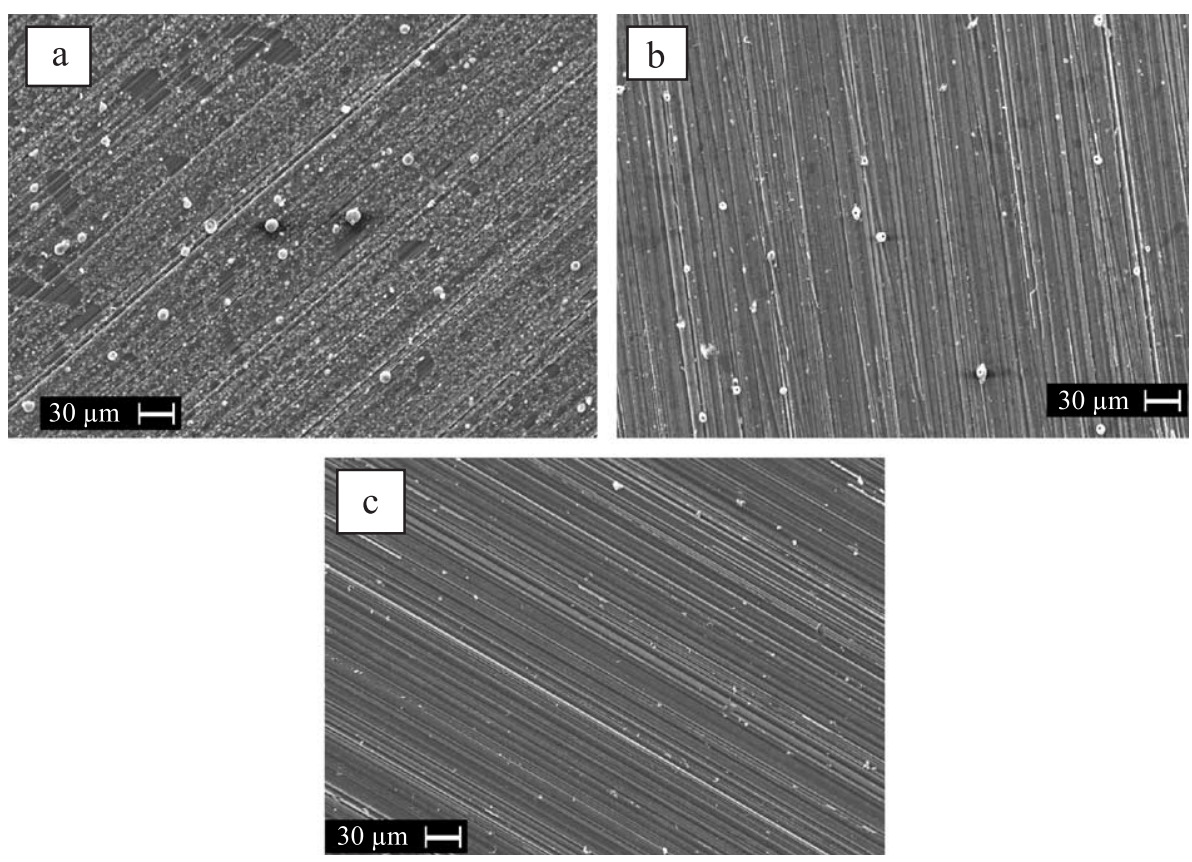

Fig. 13. AM60 surface after $5.10^{-3} \mathrm{M} \mathrm{H}_{2} \mathrm{ZrF}_{6}$ treatments with $\mathrm{KF}$ additions. (a) $10^{-3} \mathrm{M}$, (b) $10^{-2} \mathrm{M}$, and (c) $10^{-1} \mathrm{M}$.

when these latter are present in high concentration. The SEM observations provided no evidence of film formation for more concentrated $\mathrm{H}_{2} \mathrm{ZrF}_{6}$ solutions, i.e., $10^{-1}$ or $10^{-2}$ with addition of $10^{-2}-10^{-1} \mathrm{M} \mathrm{KF}$ or HF. The addition of fluoride ions to the $10^{-3} \mathrm{M} \mathrm{H}_{2} \mathrm{TiF}_{6}$ solution led to the same observations. With increasing the concentration of fluoride ions, the solutions became thus more aggressive with respect to the AM60 alloy, and less zirconium or titanium was deposited at the surface.

\section{Discussion}

The zirconium and titanium solutions have a wide range of aggressiveness towards the AM60 alloy. For both zirconium and titanium, the more concentrated solutions are more aggressive. One can think that these observations are related to the $\mathrm{pH}$ of the solutions. However, we have shown in a previous study [19] that the polarization resistance of AM60 in fluoride solutions was not influenced by the acidity of the solution in a range of $\mathrm{pH} 2-7$. On the contrary, the logarithm of polarization resistance increased to about 0.65 per $\mathrm{pF}$ unit, meaning that the most concentrated fluoride solutions were also the most aggressive with respect to AM60. Some of the solutions used here are slightly more acidic than in this previous study, and moreover, titanium solutions are slightly more acidic than the equivalent zirconium solutions since titanium IV ion is smaller than $\mathrm{Zr}$ IV ion. However, we think that the dependence of $R_{\mathrm{p}}$ with zirconium or titanium concentrations observed here is linked to the free fluoride ions concentration in the solutions. The zirconium and titanium ions have different coordination numbers [23] in aqueous solutions ( 8 for $\mathrm{Zr}$ IV and 6 for Ti IV) and certainly different complex dissociation constants. This explains the different $\log R_{\mathrm{p}}$ vs. pZr or pTi slopes observed more likely than their slight differences in $\mathrm{pH}$.

Low $\mathrm{H}_{2} \mathrm{ZrF}_{6}$ or $\mathrm{H}_{2} \mathrm{TiF}_{6}$ concentrations favour the formation of a zirconium or titanium film, in agreement with XPS measurements [20,21], except for the $10^{-3} \mathrm{M}$ $\mathrm{H}_{2} \mathrm{ZrF}_{6}$ solution. XPS analyses showed that this solution led to the films of highest zirconium content, whereas almost no film has been observed by SEM. For that solution, the film might be very thin and homogeneous, and thus, the SEM technique is not appropriate. The most effective solutions are also the least aggressive with respect to the substrate, which indicates that significant substrate dissolution is required, to obtain a film and might even prevent its formation.

Even if the SEM/EDX is not adequate to analyse the exact composition of the films due to its poor depth resolution, its lateral resolution was found to be helpful. Here, we saw that the film forms preferentially in the cathodic phases, i.e., primary solid solution and manganeserich particles. The preferential nucleation of a zirconium film on cathodic particles on aluminium alloys has recently been pointed out in Refs. [11-13]. The film formation proceeds through the reduction of water:

$\mathrm{H}_{2} \mathrm{O}+2 \mathrm{e}-\rightarrow 1 / 2 \mathrm{H}_{2}+\mathrm{OH}^{-}$.

This reaction occurs, by a galvanic coupling effect, mostly on the cathodic phases and causes the interfacial $\mathrm{pH}$ to increase locally. This increase in $\mathrm{pH}$ will lead to the acidbase precipitation of zirconium or titanium complexes, which are stable only in limited $\mathrm{pH}$ ranges [23-25]. Moreover, these observations are in good agreement with 
the surface chemistry found by our previous XPS work $[20,21]$.

The ineffectiveness of most concentrated $\mathrm{H}_{2} \mathrm{ZrF}_{6}$ or $\mathrm{H}_{2} \mathrm{TiF}_{6}$ solutions is probably related to their high aggressiveness due to fluoride ions and the nature of the zirconium and titanium complexes under these conditions.

Further study will be needed in order to determine the level of corrosion protection provided by these films. However, we suggest that the primary $\alpha$ phase which is not covered by the film and has a tendency to corrode first in aggressive media [22] will act as defect points.

\section{Conclusions}

The zirconium or titanium-containing film formed at the surface of AM60 magnesium alloy is in most cases heterogeneous. The film formation proceeds by precipitation of the $\mathrm{Zr}$ and $\mathrm{Ti}$ complexes initiated by the increase of interfacial $\mathrm{pH}$ related to the reduction of water. The more dilute solutions are most effective in the formation of a film. This is related to the fluoride ions' influence on the electrochemical behaviour of AM60 and also to the nature of $\mathrm{Ti}$ and $\mathrm{Zr}$ complexes. An alkalinization of the solution seems to favour the formation of this film, whereas fluoride additions were found to have a detrimental effect.

\section{References}

[1] E. Ghali, in: R. Winston Revie (Ed.), Uhlig's Corrosion Handbook, 2nd edition, 2000, p. 793.

[2] J.D. Hanawalt, C.E. Nelson, J.A. Peloubet, Trans. AIME 147 (1942) 273.

[3] J.E. Gray, B. Luan, J. Alloys Compd. 336 (2002) 88.

[4] C.E. Tomlinson, Proc., Electrochem. Soc. 95 (1995) 159.
[5] P.D. Deck, D.W. Reichgott, Metal Finish. 9 (1992) 29.

[6] S.E. Hörnström, J. Karlsson, A. Östling, Proc. of Eurocorr 94, vol. 1, Bournemouth, UK, 1994, p. 35.

[7] T. Schram, G. Goeminne, H. Terryn, W. Vanhoolst, P. Van Espen, Trans. I.M.F. 73 (1995) 91.

[8] L. Fedrizzi, F. Deflorian, P.L. Bonora, Electrochim. Acta 42 (1997) 969.

[9] L. Fedrizzi, F. Deflorian, S. Rossi, ATB Metallurgie 37 (1997) 243.

[10] S. Delalande, M. Moustamsik, M. Capelle, Proc. of The 2nd Aluminium Surface Science and Technology International Symposium, Manchester, United Kingdom, 2000, p. 113.

[11] O. Lunder, K.F. Heen, J. Walmsley, K. Nisancioglu, Proc. of the 3rd Aluminium Surface Science and Technology International Symposium, Bonn, Germany, 2003.

[12] O. Lunder, J.C. Walmsley, Y. Yu, A. Aytac, K. Nisancioglu, Proc. of the 15th Internat. Corrosion Congress, Grenada, Spain, 2002, p. 386.

[13] J.A. Nordlien, J.C. Walmsley, H. Østerberg, K. Nisancioglu, Surf. Coat. Technol. 153 (2002) 72.

[14] P. Puomi, H.M. Fagerholm, J.B. Rosenholm, R. Sipilä, Surf. Coat. Technol. 115 (1999) 79.

[15] P. Puomi, H.M. Fagerholm, J.B. Rosenholm, K. Jyrkäs, Surf. Coat Technol. 115 (1999) 70.

[16] H. Gehmecker, Proc. of The 51st World Conference of Magnesium, 1994, p. 32.

[17] J.I. Skar, Met. Finish. 93 (1995) 34.

[18] G. Guerci, C. Mus, K. Stewart, Proc. of Magnesium Alloys and Their Applications, Munich, Germany, 2000, p. 484.

[19] S. Verdier, S. Delalande, N. Van der Laak, J. Metson, F. Dalard, Appl. Surf. Sci. 235 (2004) 513.

[20] S. Delalande, S. Verdier, N. Van der Laak, J. Metson, F. Dalard, ECASIA'03 International Congress, October 5-10 2003, Berlin, Germany, 2003, p. 390.

[21] S. Verdier, S. Delalande, N. Van der Laak, J. Metson, F. Dalard, Surf. Interface Anal., in press.

[22] S. Verdier, PhD Thesis, Institut National Polytechnique de Grenoble, 2003.

[23] J.P. Jolivet, De la solution à l'oxyde, Savoir Actuels (Ed.), InterEditions/CNRS Editions, 1994.

[24] M. Pourbaix, J. Van Muylder, Atlas D'équilibres Électrochimiques, Gauthier-Villars et Cie, Paris, 1963, p. 168.

[25] M. Pourbaix, J. Van Muylder, Atlas D'équilibres Électrochimiques, Gauthier-Villars et Cie, Paris, 1963, p. 223. 